\title{
Government Capacity in Coping with COVID-19 in Bandung City
}

\author{
Leo Agustino ${ }^{1^{*}}$, Mona Sylviana, ${ }^{2}$ and Ayuning Budiati ${ }^{1}$ \\ ${ }^{1}$ Department of Public Administration, Universitas Sultan Ageng Tirtayasa, Serang, Indonesia, \\ 2Institut Nalar, Bandung, Indonesia
}

How to cite: Agustino, Leo., Sylviana, Mona., \& Budiati, Ayuning. (2021). Government Capacity in Coping with COVID-19 in Bandung City. Jurnal Borneo Administrator, 17 (3), 275-290. https://doi.org/10.24258/jba.v17i3.847

\section{Article History}

Received: 28 February 2021

Accepted: 06 August 2021

\section{Keywords:}

COVID-19,

State Capacity,

Government,

Bandung City Government

\section{ABSTRACT}

This article analyzes the capacity of the Bandung City Government to handle the COVID-19 pandemic. There is a gap between the policies implemented and the high curve of the spread of the virus in Bandung city. This study used a qualitative approach, and the data sources were from various documents, observations, and interviews. This article finds two factors that influence the capacity of the Bandung City Government: (i) the relationship between the central government and regional governments and (ii) the capacity of individuals to process information and exercise discretion. The weak capacity of the Bandung City Government affects trust, which has implications for the low participation of Bandung City residents. The article that elaborates on the state (government) capacity approach from Williams (2019) shows that individual capacity directly affects government capacity in crisis conditions, such as the COVID-19 pandemic.

\section{A. INTRODUCTION}

The Coronavirus Disease 2019 (COVID-19) pandemic is acknowledged as a communal problem, and it is obligated for every country to implement mitigations. Almost all countries in the world are not prepared to face this crisis. The COVID-19 pandemic is a great challenge for the state emergency resilience, which requires a diverse range of mitigation acts; highly dependent on the health care system, government system and structure, leadership, public health paradigm, and the financial capacity of each country (Popovic, 2020). Thus, as of July 16th, 2021, COVID-19 has spread to 222 countries with $189,925,125$ confirmed cases and 4,086,195 deaths (Worldometers, 2021).

Since it was discovered that citizens were infected with COVID-19 in March 2020, the Government of Indonesia issued various policies at the central government level to the city/regional level, starting from the Presidential Decree No. 7/2020 on the Establishment of COVID-19 Response Acceleration Task Force. However, the policy was considered too late, flippant, and giving the impression of a lack of understanding about COVID-19 and its impacts (Mas'udi \& Winanti, 2020). While many countries had anticipated the spread of COVID-19, The Government of Indonesia had yet to mitigate it (Djalante et al., 2020), even conveying negative and anti-science narratives and denial of scientific data (Agustino, 2020). In addition, the politicization of government elites had also dulled the capability in coordination and effective

* Corresponding Author

Email : leo.agustino@untirta.ac.id

(C) 2021 Training, Development, and Study for Decentralization and Regional Autonomy Centre (Pusat Pelatihan dan Pengembangan dan Kajian Desentralisasi dan Otonomi Daerah - Puslatbang KDOD), State Administration Agency, Indonesia. 
responses between the central and the regions and between the government and the public (Jaffrey, 2020).

After the statement from the central government, the West Java Governor, Ridwan Kamil (RK), immediately promulgated that West Java was in alert level 1 (Ritonga, 2020), followed by Bandung City Government issuing Mayoral Decree No 443/Kep.239-Dinkes/2020 and Mayor Regulation No. 13/2020. These policies were the legal bases for establishing the COVID-19 Response Acceleration Task Force (Now: COVID-19 Handling Task Force). The Bandung City Government coordinated inter-agency activities to deal with the pandemic. On April $22^{\text {th }}, 2020$, through Mayor Regulation No. 14/2020 as a follow-up to the Decree of Minister of Health No. HK.01.07/Menkes/259/2020, Bandung City implemented Large Scale Social Restrictions (Pembatasan Sosial Berskala Besar - PSBB), which proceeded to Mayor Regulation No. 68/2021 on Emergency Restrictions towards Community Activities on July 3rd, 2021.

During the COVID-19 pandemic, some cases stood out in Bandung City: 1,280 cases in Army Officer Candidate School (Calon Perwira Angkatan Darat - Secapa AD), a cluster in Regional Government (Pemerintah Daerah - Pemda) Office of Bandung City with 180 confirmed cases and new clusters (traditional market cluster, holiday cluster, family cluster). On December 4th, 2020, the mayor of Bandung issued Mayor Regulation No. 73/2020 to implement Proportional PSBB to respond to Bandung City's status as a high-risk zone (score 1.65). Following that, on July 13th, 2021, 959 people were infected by the virus - the highest number throughout the pandemic in Bandung City. Other than the direct impact on the health sector, Bandung City experienced domino effects in economic, religious, educational, sociocultural, and political sectors (Iqbal, 2021; Naurah \& Ferdianti, 2020; Perdana, 2020b; Riyadi, 2021; Yuantisya, 2021).

After various policies for dealing with the pandemic were implemented, it turned out that COVID-19 in Bandung city still could not be taken under control. COVID-19 pandemic is not an ordinary phenomenon but a systemic crisis that bears the risk or possibility of damage throughout the system due to the high level of connectivity, uncertainty, ambiguity, and causing non-linear relationship effects (IRGC, 2017). In crises, the government is faced with many paradoxical phenomena: the need to have analyzed for appropriate and fast policy-making, mechanisms that accommodate both centralized and also decentralized interests and policies, innovation in bureaucratic mechanisms and established organizational cultures, the involvement of scientific narratives along with political narratives (Janssen \& Voort, 2020), the tension between information transparency and disclosure of private information, coordination, and flexibility in the field (Kim et al., 2020).

These paradoxical relationships brought consequences for the Regional Government Capacity to handle the pandemic, where real pandemic problems were within its scope, e.g., treatment at regional hospitals and referral hospitals, overcoming successive impacts, and efforts to involve citizens' participation. The concept of government (state) capacity, in general, is the government's ability to formulate and implement various policies that provide public services, including the government's ability to organize and manage its programs (Mann, 1984; Skocpol, 1985; Soifer, 2008). According to Williams (2019), state capacity analysis provides optimal results if it fulfils certain conditions. For example, it explicitly showed the bureaucracy as a collective actor, directly involved with policy implementation's contingencies and specifics without being represented by one-dimensional constructs and distinguishing between actual actions and hypothetical potentials.

Several studies on COVID-19 pandemic handling related to state capacity and central-regional relations have been conducted. Herdiana et al. (2021) look at handling COVID-19 in Indonesia through policy/regulatory aspects, human resources, organizational restructuring, and a budget reallocation. This study analyzes solutions that Williams criticizes, i.e., "general ideas" for complex bureaucracies. Santoso's study (Santoso, 2020) examines the relationship between the central and regional governments in handling the pandemic in Indonesia but does not specifically discuss the state's capacity. Meanwhile, Janssen \& Voort (2020) examines the Dutch 
Government's handling of COVID-19 through an analysis of "agile and adaptive governance," which does not specifically link the state capacity and central-regional relations. Then how is the capacity of the Bandung City Government in handling the COVID-19 pandemic? Why, even after so many policies, the contagion curve is still unstable? These are the questions that the author discusses in this article.

\section{B. LITERATURE REVIEW}

The concept of state capacity, in general, refers to the concept from Michael Mann (1984:189), the state infrastructural power, "... the capacity of the state actually to penetrate civil society, and to implement logistically political decisions throughout the realm." In its development, the state infrastructural power also refers to the capacity of the state to assess the function of the state bureaucracy, the relationship between the state and social actors, and its spatial and social reach (Soifer \& Hau, 2008). Furthermore, even explain long-term political changes, differences in sustainable economic development, and politics through the ability to control territory, increase income, implementing effective bureaucracy and services (Lindvall \& Teorell, 2016).

Other scholars provide different understandings. Besley \& Persson (2011:6) state that, "the institutional capacity of the state to implement various policies that provide benefits and services to the community and companies." Kaufmann et al. (2015:4) define it as, "the capacity of the government to formulate and implement sound policies effectively." Centeno et al. (2017:3) understand it as, "the ability of organizations and bureaucracy to implement government projects." Andrews et al. (2017:95) define it as, "the ability of organizations to equip, activate, and encourage their agents to do the right things at the right time to achieve normative policy objectives."

This diversity enriches understanding as well as draws criticism. In general, the issues in question are (i) generalization of the assessment with state capacity as a benchmark in certain countries and a certain period, (ii) tautological and circular reasoning that relate certain areas of study (economic, social, or political outcomes) with the capacity of a country performing certain functions, (iii) the weakness of the theoretical foundation so that various definitions, trends, and phenomena are integrated into one term (D'Arcy \& Nistotskaya, 2020; Gomide \& Pereira, 2018; Kocher, 2010; Lindvall \& Teorell, 2016; Soifer \& Hau, 2008).

Williams (2019) criticizes that the study of state capacity related to bureaucratic functions bureaucratic performance and policy implementation - uses a broad concept: it covers almost everything the government does. For example, personnel indicators are measured as organizational capacity (Ang, 2016; Bersch et al., 2017). Institutional reform is referred to as a capacity-building problem (Andrews et al., 2017; Baser, 2011). Implementing certain policies is analyzed as a capacity issue (Baker, 2010; Hills, 2007), and impact evaluation is framed as a country's capacity through programs (Zandamela \& Mphahlele, 2021). Meanwhile, studies that analyze bureaucratic actions - past, present, or future - always link the potential and activities of the bureaucracy. This study model the government bureaucracy as a unit of agents with limited skills, knowledge, resources, etc. Thus, "capacity" obscures the mechanisms that determine bureaucratic performance and policy implementation.

"Capacity" also often refers to the hypothetical potentials of the bureaucracy to implement policies, which, in reality, differs from actual actions. This kind of study fails to understand bureaucracy as a collection of individuals that cannot be seen as limited to the capacity of individuals and should be seen as collective bureaucracies of many agencies whose operational efficiency relies heavily on problem-solving, credibility, and clarity (Garicano \& Rayo, 2016; Gibbons \& Henderson, 2012). Government policy is not a clear-cut decision from a single political principle but an unstable and incomplete expression of a constantly changing collective choice of the political tenets (Shepsle, 1992; Wilson, 1989). 
Therefore, according to Williams, there are three sets of collective problems that undermine the coherence of capacity analysis: (i) information and incentive problems that undermine the ability of individuals to collaborate efficiently, (ii) problems of allocating individual capacities within organizations; and (iii) relational contract issues and organizational culture as balancing potentials in organizational performance. The first and second problems imply that there is only a weak correlation between organizational performance and the capacity of individual members. The third issue confirms the argument that a lack of individual capacity is not even likely to be a constraint for most organizations.

The problems of information and incentives stem from the idea that individual capacity is centred on the individual's ability to complete a task. However, individuals face challenges in coordinating their activities, issues of information distribution, and ethics. Garicano \& Rayo (2016,:138-139) sums up aptly,

"Agents fail to act together because they do not want to (an incentive problem) or they do not know how to (a bounded-rationality problem). Incentive problems arise due to asymmetric information or imperfect commitment, which lead agents to act according to their own biases or preferences rather than in the organization's interest (e.g., Holmstrom, 1979; Shavell, 1979). Bounded-rationality problems arise due to agents' cognitive limitations and finite time, which means that even if they want to, agents cannot compute the solution to every problem, nor can they make themselves precisely understood by others ...."

The problem of allocation is related to complementarity in collective work. The assumption is that if each individual performs his/her task component well, the overall task can be achieved: the cumulative individual capacity for team performance. Problems arise, especially in public institutions, when individuals from various units are involved, for example, providing input that tends to come from multiple aspects for a single policy/program. The next problem is relational contracts and organizational culture that can balance organizational performance. This theory stems from the understanding that many important aspects of organizational functioning cannot be fully formalized (Gibbons \& Henderson, 2012). It relies heavily on the informal understanding of individuals, who often need discretion - although discretion is a double-edged sword: increasing efficiency while also vulnerable to being misused for short-term personal gain. Discretion is both technical (specific, contingent, and incentive design) as well as relational (mutual understanding and development of shared norms are processes that gradually become a "habit").

Therefore, Williams (2019) suggests three approaches. First, research on organizational performance and reform must explicitly involve the implications of bureaucracy as a collective actor. Second, the analysis must engage directly with the contingencies and specifics of policy implementation - which are not well represented by one-dimensional constructs that are assumed to improve capacity at the national, regional, or other institutional levels. Third, distinguish between actual actions and hypothetical potentials - where retrospective capacity can be measured, while prospective capacity can be ascertained as speculative.

Williams' (2019) approach helps analyze Bandung City Government's capacity to handle the COVID-19 pandemic. Sporadic handling of crises without preparations results in treatments determined by non-medical factors. At this point, the individual's capacity gets to act on discretion - referring to functionally new solutions (allowing new things to be implemented) or significant improvements in the performance of existing solutions (Hartmann \& Hartmann, 2021). Because, as Hill (2005:265) says, policy-as-designed or policy-as-written "often fails to teach implementers what they need to know to do policy." Discretion is an effective strategy to deal with crises, which are full of uncertainty, policy ambiguity, increased service needs, high work pressure, and limited resources (Gofen \& Lotta, 2021). 


\section{METHOD}

This article used a qualitative approach with a case study method that aimed to describe the capacity of the Bandung City Government to handle the COVID-19 pandemic in Bandung City. In line with the understanding of case study as stated by Merriam (1998:xiii), i.e., “... an intensive, holistic description, and analysis of a bounded phenomenon such as a program, an institution, a person, a process, or a social unit."

The data sources for this article were obtained from document studies, interviews, and observations. The document data were in the form of official government documents (laws and policy texts and their derivatives), books, journals, mass media articles (offline and/or online), and websites. The data collection techniques relied more on document review due to the author's limited space in the COVID-19 pandemic. Observations were made in several places identified as get-together points, like on Jl. Dipati Ukur (Jl. is Jalan, which means "Street" in the Indonesian language), Jl. Diponegoro, Jl. Merdeka, Gedebage traditional market, Sederhana traditional market, Paris van Java Mall, and Trans Studio Mall. The unstructured interviews were conducted randomly to several interviewees when making observations and during the data verification process. Data analysis techniques were carried out by reducing data, presenting data, and drawing conclusions (Creswell, 2009).

\section{RESULT AND DISCUSSION Political Noise in Crisis}

After the Director-General of WHO declared a Public Health Emergency of International Concern due to COVID-19, Several countries prepared themselves. The Government of Vietnam collaborated with WHO to conduct Go. Data training for epidemiologists, members of the Rapid Response Teams, and frontline pandemic workers; as resources for investigation (field data collection, case investigation, contact tracing and follow-up, visualization of transmission chain, and real-time data exchange) (WHO, 2020). Meanwhile, the Government of Singapore closed entertainment venues, schools, and places of worship; even some countries have implemented lockdown (Agustino \& Wicaksana, 2020). Indonesia was the opposite.

At the beginning of the COVID-19 pandemic, the Government of Indonesia had not undertaken significant mitigatory measures. The government and political elites flippantly responded to the news of COVID-19 and even tended to belittle it (Agustino, 2020). Research conducted by Institute for Research, Education, and Information on Economy and Social Affairs (Lembaga Penelitian, Pendidikan, dan Penerangan Ekonomi dan Sosial - LP3ES) stated that from January to April 2020, there were 37 blunder statements from the government elites (Farisa, 2020). The random statements in the mass media were confusing and fostered fake news/hoaxes. From the monitoring of the Ministry of Communication and Information Technology (Kominfo, 2020), from January to April 2020, 562 hoaxes had spread, which, among other things, caused panic buying, anxiety, and negative stigma for those who were infected (Hikam, 2020). And, detrimental to the already emergency, the hoaxes impair the public's trust in the government.

Several steps and policies that the government later took were not appropriate. For example, the policy of economic incentives to bring in foreign tourists (Sitorus \& Rahmadi, 2021); disinformation (SE No. HK.02.01/MENKES/199/2020 it says that the virus dies within 5-15 minutes); institutional disputes (the Indonesian Doctors Association over data (Bramasta, 2020)); overlapping policies (online taxi transportation is permitted by Regulation of The Minister of Transportation No. 18/2020 while Regulation of The Minister of Health No. 9/2020 restricts and prohibits). This was exacerbated by the polemic between the central and regional governments. However, the central government had issued Presidential Decree No. 7/2020 and Decree of The Minister of Health No. HK.01.07/Menkes/104/2020 concerning the Stipulation of 2019-nCoV Infection as a Disease that Can Cause Outbreaks and Efforts to Overcome It. However, there were 
no concrete steps or clear instructions to curb the spread of the virus that the regional government could take.

Several regions then stepped forward. In January 2020, The Muara Enim Regency Government formed a special team to monitor foreigners visiting the Muara Enim Regency and monthly report residents' health status to the governor. In March 2020, Papua Province closed access to the sea and air transportation; Maluku province closed flight and shipping routes; Bali Province issued an advisory to work, study, and worship at home, and reduce activities; Tegal City closed the way in and out of the city; Solo City closed schools, abolished car-free day events and large mass events, and closed tourist sites; Banda Aceh City Government implemented a local lockdown; West Sumatra Province had tightened entry routes across its borders.

The central government opposed the policies of several regional governments. Through the @jokowi account (March 16th, 2020), President Joko Widodo (Jokowi) tweeted, "Lockdown policies both at the national and regional levels, for example, are in the discretion of the central government. And we haven't thought in that direction. What needs to be done is social distancing, which is reducing people's mobility, maintaining distance, and reducing crowds." In a Limited Meeting on April 2nd, 2020, Jokowi reprimanded regional heads who closed areas or entrances to obstruct basic needs and food (Ihsanuddin \& Hakim, 2020). Jokowi's statement was not without basis. In Law of The Republic of Indonesia No. 6/2018 concerning Health Quarantine, it is stated that regional quarantine is a central government policy.

Looking at Presidential Decree No. 7/2020, Law of The Republic of Indonesia No. 6/2018, Law of The Republic of Indonesia No. 7/1984 concerning Epidemic and Infectious Diseases, Law of The Republic of Indonesia No. 24/2007 on Disaster Management, and Law of The Republic of Indonesia No.36/2009 on Health, these four have relatively different approaches to seeing the role and position of the regional government. The first three laws emphasize handling a tiered model (decentralization), while the latter gives the central government a dominant role. In addition, there is a long list of changes to regional governance - Law of The Republic of Indonesia No. 2/2015 on the Stipulation of Regulation of The Government in Lieu of Law of Republic of Indonesia No. 2/2014 on Amendments to Law of The Republic of Indonesia No. 23/2014 on Regional Government Becoming a Law; and Law of The Republic of Indonesia No. 9/2015 concerning the Second Amendment to Law No. 23/2014 on Regional Government. UU No. 2/2015 - which can legitimize the region to determine its attitude as an autonomous region (devolution) because it is the responsibility (of the regional head) to serve and protect its constituents (Santoso, 2020). Legally, the pattern of central-regional relations is ambiguous, but the handling of the pandemic is centralized in practice. Regional governments do not have strategic authorities. The regional governments' handling of the pandemic is more of a support system, and its position is to implement the central government's policies.

Centralization appeared in the structure of the COVID-19 handling institution. The establishment of the Bandung City COVID-19 Response Acceleration Task Force was based on Presidential Decree No. 9/2020, stating that governors and regents/mayors should form a Regional Task Force based on the considerations and recommendations Chief Executive of the Task Force (Article 11). Circular Letter of The Minister of Home Affairs No. 440/2622/SJ directed the regional head as the head of the Regional COVID-19 Task Force to prepare the organizational structure and committee to be guided by the Circular Letter Minister of Home Affairs. Data collection at the beginning of the pandemic was also centralized. The regional governments have difficulty accessing the data because of the COVID-19 examination in Jakarta. Ridwan Kamil (RK), Governor of West Java, said "Yesterday, in the first days, the data were blank, so the regional government was confused about where to trace, there were no data" (BBCNews, 2020). After the COVID-19 Examination Laboratory Network was established, the central government asked the Regional Government and the regional COVID-19 Task Force to report data findings to the central 
government. To reduce panic, the government ensures that information comes out of "one door" before being conveyed to the public (Detikcom, 2020).

Such was the case with the implementation of PSBB. The implementation of PSBB in regions was regulated in the regulation attachment of the Minister of Health No. 9 of 2020. If a region wants to implement PSBB, the Regional Government must fulfil several conditions (Article 2). There is a significant increase in the number of cases and/or deaths, and there is an epidemiological link with similar events in other regions or countries. The regional head (governor/regent/mayor) proposes the requirements, including data on the increase in the number of cases along with the transmission epidemiology curve, data on the increase in the number of spreads according to time, and the incidence of local transmission.

Moreover, regional heads must also showcase the region's readiness in the availability of people's basic living needs, health infrastructure facilities, budgeting and operationalization of social safety nets, and security aspects. After that, a special team from the Ministry of Health, in collaboration with the COVID-19 Task Force, will conduct epidemiological and regional readiness studies as recommendation material. At least two days after the submission, the Minister of Health will make a decision. In the case of Bandung City, the Minister of Health approved the PSBB on April 17th and became effective on April 22nd. In that time, you can imagine the transmission during the PSBB pending approval and preparation process, which had a reproductive number of 1.14 , meaning one person infected at least one other person.

The centralization hinders the regional governments' steps. This affects the trust and participation of citizens. Several studies have also shown a correlation between government capacity and community participation (Kuipers et al., 2020; Ladiqi, 2020; Mujani, 2020; Mujani \& Irvani, 2020). For more than six months, the author observed that the participation of the citizens of Bandung City in the form of non-compliance increased. After implementing PSBB and Proportional PSBB, places once prohibited from operating by Bandung City Government were increasingly swarmed by people. The roadside stalls along Jl. Dipatiukur - which in September 2020 was blocked by Bandung City COVID-19 Task Force - could never be fully emptied. The buyers approached the sellers on foot, leaving their vehicles around J1. Singaperbangsa drifted to the stalls around Taman Gesit (only 500 meters from the closed location). Sellers around J1. Diponegoro, which was closed, drifted slightly to Jl. Citarum. This condition even showed the "participation" of sellers and buyers in finding other gathering points. The author also found several coffee shops swarmed with visitors - mostly high school and university students - who often ignored health protocols, like washing hands and keeping a safe distance. Some still use buff masks (motorcycle masks) or scuba masks.

Table 1. Total Number, Types of violations, and Types of Sanctions

\begin{tabular}{|c|c|c|c|c|}
\hline No & Date & Total & Violations & Sanctions \\
\hline 1 & 13- 31 August 2020 & 370 & 1. No masks; & 1. Verbal warning; \\
\hline 2 & 1-10 September 2020 & 101 & 2. Crowds; & 2. Written warning; \\
\hline 3 & 11-28 September 2020 & 238 & 3. Exceeding space & 3. Community service; \\
\hline 4 & 27 Jan - 5 Feb 2021 & 504 & capacity; & 4. Temporarily \\
\hline 5 & $6-18$ February 2021 & 758 & $\begin{array}{l}\text { 4. Exceeding } \\
\text { operational hours: } \\
\text { 5. No Hand Sanitizers }\end{array}$ & $\begin{array}{l}\text { suspending activities; } \\
\text { 5. light punishment } \\
\text { (push up on the spot). }\end{array}$ \\
\hline
\end{tabular}

Source: The data were processed from various sources (2021)

From observation and interview data from December 2020 to January 2021, there were at least three causes of non-compliance. Firstly, the economic factor. Several culinary sellers on the 
roadside of Jl. Diponegoro said ${ }^{1}$ that either PSBB or any other similar names for such restrictions had killed their source of income. They continued to sell in forbidden places or went around because there was no assurance from the government to meet subsistence needs.

Interestingly, none of them, whom the author interviewed, had received any socialization from the government (including Bandung City COVID-19 Task Force). ${ }^{2}$ Secondly, sanctions that were imposed did not have a deterrent effect (see Table 1). Thirdly, there were still some residents of Bandung City who did not understand the perils of COVID-19. Several interviewees answered that the virus could only be transmitted through droplets from infected, as stated by a student at a coffee shop on Jl. LLRE Martadinata, "If you wear a mask, and no positive person is sneezing or talking, it's okay." 3

The low level of public participation made the regional governments work harder than they should have to become the "single actor on the stage." This could be tolerated at the pandemic's beginning because the public and the government had not experienced being in crises. However, the reduced participation in handling the pandemic that had been going on for some time was undeniably a reflection of the people's responses to the government's capacity to handle the pandemic. Various rules and policies turned out to be dysfunctional in solving their problems in the pandemic.

\section{Asymmetry of Information and The Infected Regional Government Elites}

An Individual's ability to process critical information in a pandemic will increase the institution capacity because it can be a reference for general public understanding, a strong foundation for implementing policies, guidelines for discretion, and espousing coordination among individuals. On the other hand, the inability to process information results in an asymmetry of information. This may not be an intentional factor - not wanting to find information - but because the information obtained is incomplete, the source is invalid, or the low cognitive ability in understanding the information.

Standardization of masks can be used as a representative case study. Through the DirectorGeneral of Disease Prevention and Control, the Ministry of Health stated that the use of scuba masks did not meet health standards as the pores were too wide (kemkes.go.id, 2020). West Java Provincial Government, which had spent IDR 40 billion to order this mask, immediately modified the specifications for the 8 million masks ordered (kumparan, 2020). The Deputy Mayor of Bandung, Yana Mulyana, had a different response. He stated that scuba masks could still be used by asymptomatic people (Orang Tanpa Gejala - OTG) (Ramadhan, 2020). The response was problematic because, in a pandemic, the information does affect not only cognitive aspects but also safety. Information asymmetry might have caused around 189 State Civil Apparatus (Aparatur Sipil Negara - ASN) and Bandung City employees infected with COVID-19 (Perdana, 2020a). In January 2021, the Mayor of Bandung, Oded M. Danial, was also infected with COVID19. In July 2021, the Personnel and Human Resources Development Agency of Bandung City reported that 772 ASN and non-ASN were infected with COVID-19 (Rinaldo, 2021).

Asymmetry of information also disrupted coordination-for example, the implementation of Micro-Scale Social Restrictions (Pembatasan Sosial Berskala Micro - PSBM). The RW (Rukun Warga - Hamlet) Forum said that there was no coordination, either from the City Government or the Task Force in the field. Several RWs had also implemented PSBM without coordination with the urban village (Kelurahan) or sub-district (Kecamatan) (Wijanarko, 2020). Ema Sumarna, the Regional Secretary of Bandung City, who is also the Daily Chief of COVID-19 Task Force of Bandung City, stated that coordinating with the RW forum was not the obligation of the City Government but the Heads of sub-district and urban village (Azzis Zulkhairil, 2020). Coordination

\footnotetext{
${ }^{1}$ Interviewed on January $3^{\text {rd }}, 2021$.

${ }^{2}$ Interviewed on December $15^{\text {th }}, 2020$ and December $28^{\text {th }}, 2020$.

${ }^{3}$ Interviewed on December $27^{\text {th }}, 2020$.
} 
between Bandung City Government and the ranks below also occurred regarding data collection (Zulkhairil, 2021a).

The inability of individuals to process information increasingly affects the capacity of institutions when it comes down to policy-for example, the policy of opening cinemas. Yana Mulyana said it was possible to open cinemas since COVID-19 cases had been under control as the reproduction number of the virus was already below 1, even though Bandung City was still a red zone (CNNIndonesia, 2020). The Head of Health Office of Bandung City, Rita Verita, considered this as a risky policy. She added, "Surely people know whether this (the opening of cinemas) is safe or not. It's a minimum of two hours inside the studio (closed and airconditioned)." (Simbolon, 2020). Mayor's Circular Letter No. 443/SE.030-Dinkes was also problematic. On the one hand, Bandung City Government had temporarily closed governmentowned public areas (Bandung Square, City Park, Bandung Planning Gallery, Bandung City Museum, Bandung Creative Hub, Bandung Command Center); urged all agencies, offices, places of worship, stations, terminals, airports, and tourism businesses to apply health protocols; and implemented distance learning. On the other hand, public services were still running as usual, and did not carry out strict controls in traditional markets, shops, malls, and others; which were the points where people usually had a get-together. In fact, with precise information about the virus resistance (see research by Doremalen et al. (2020)), policies that instigated public outrage would not have occurred.

\section{Dislocation of Apparatus Allocation: Steps Minus Discretion}

The Center does not appoint epidemiologists, virologists, or public health officers in the COVID-19 Response Committee and National Economic Recovery as "commanders" for handling the pandemic. In contrast to Taiwan, which appointed the Minister of Health and Welfare and the Vice President, an epidemiologist and virologist - as the driving force for handling COVID-19. This choice successfully minimized Taiwan impact pandemic, a country close to the epicentre of the virus. The South Korean government had also appointed experienced epidemiologists from the Korea Centers for Disease Control as commanders for handling COVID-19 and the Epidemic Intelligence Service as the main officers in the field (Kim et al., 2020).

The Government of Indonesia instead appointed members of the military and police in a central position. The head of the COVID-19 Task Force was a lieutenant general (Lieutenant General Doni Monardo which later replaced by Lieutenant General Ganip Warsito), assisted by two major generals (the Operations Assistant for the TNI Commander-in-Chief and the Operations Assistant for the Chief of Indonesian National Police). Meanwhile, at KPCPEN, the Chief Executive of KPCPEN was an entrepreneur (and serving in BUMN) assisted by the Chief of Staff of the Army, General Andika Perkasa, as Deputy Chief, and Deputy Chief of the National Police Commissioner General Gatot Eddy Pramono as Deputy Chief Executive II. In the cabinet, the Minister of Health was a lieutenant general (retired from the armed forces), who was later replaced by a "manager", an ITB (Institut Teknologi Bandung - Bandung Institute of Technology) graduate, Budi Gunadi Sadikin.

The placement of the apparatus in the Bandung City COVID-19 handling institution was the same. Mayoral Decree No. 443/Kep.239-Dinkes/2020 appointed the Mayor of Bandung as Chief; the Commander of Kodim 0618/BS, Bandung Chief of Metropolitan Police, Bandung State Attorney, Deputy Mayor of Bandung, Bandung City Military Police Detachment Commander III/5, Commander of Husein Sastranegara Air Base, and Bandung Navy Base Commander as Deputy Chiefs; Bandung City Secretary as the Daily Chief Executive; Head of Bandung City Fire and Disaster Relief Office as the Secretary Bandung City COVID-19 pandemic handling institution (once again) did not appoint competent people in the pandemic. 
The institutional structure for handling the pandemic was problematic because of the government apparatus. Considering the characteristics of public institutions which tend to be hierarchical, procedural, static (status quo), rigid, formalistic, and having weak work ethics (Bozeman, 1987; Perry \& Rainey, 1988; Weber, 2007) - was accustomed to being in a comfort zone and doing repetitive routine work. Meanwhile, crises require the ability to think and act "out of the box", which cannot be immediately acquired, so discretion is quite unlikely (not to say, impossible) to be exercised.

The stagnation of individual discretion negatively contributes to Bandung City Government's ability to collaborate and innovate. Collaborative governance, according to Ansell \& Gash (2008), adheres to the following principles: (i) parties that influence each other, (ii) interaction between stakeholders, (iii) commitments and targets to be achieved, and (iv) the principles of transparency, participation, accountability, efficiency, effectivity, and consensus. With many social media users in Bandung (see Table 2) in Era 5.0, collaboration through social media is a strategic and effective choice. Moreover, Bandung City has no shortage of influencers (strategic actors) to be involved, including Abdullah Gymnastiar and ustadz Adi Hidayat (religious figures), Rizky Febian and Isnaya Sarasvati (actor and actress), Entis Sutisna or Sule (comedian), Helmi Nursifah, Fani Rahmi, Anselma Putri, and Rachel Vennya (Youtuber/vlogger/celebgram). With those names accruing millions of followers, then (it can be assumed) the socialization of pandemic handling had spread widely - compared to conventional socialization.

Table 2. The Percentage of Bandung City Residents Using Social Media 2020

\begin{tabular}{lccc} 
& Male & Female & Male+Female \\
Get Information/News & 72,40 & 65,83 & 69,22 \\
Do Homework & 25,37 & 27,85 & 26,52 \\
Send/Receive Email & 20,19 & 16,25 & 18,28 \\
Social Media/Social Network & 90,63 & 90,75 & 90,71 \\
Buy/Sell Goods/Services & 20,07 & 29,42 & 24,60 \\
Entertainment & 67,58 & 61,08 & 64,43 \\
Financial Facility & 13,38 & 11,59 & 12,51 \\
Others & 2,77 & 1,33 & 2,07 \\
\hline
\end{tabular}

Source: Walfare Statistics of Jawa Barat Provice (2000)

However, the finding of a lack of collaboration was denied by the Bandung Deputy Chief of Metropolitan Police, who was also the Daily Deputy Chief Executive of the COVID-19 Task Force, Adjunct Senior Commissioner Yade S. Ujung. He stated, "We have collaborated with various communities, where these communities have become ambassadors and pioneers of the disciplinary movement to apply health protocol standards. As of November 2020, in Bandung Metropolitan Police jurisdiction, there have been 173,222 communities that have declared themselves to be the Tohaga Lodaya Community." 4 Surprisingly, with a relatively large number of communities, it did not affect the spread curve of COVID-19. Thus, the mechanism and effectiveness of the collaboration implemented were interesting to another research topic.

Bandung City Government used digital platforms for socialization; https://covid19. bandung.go.id/ site and the Pusicov Bandung application. The management of the portal and application had not been maximized in terms of content and technicalities. In September 2020,

\footnotetext{
${ }^{4}$ Interviewed on December $14^{\text {th }}, 2020$.
} 
residents could not access the site for more than 11 days (Anshori, 2020). and it was not uncommon for the COVID-19 case data to differ from West Java's Pikobar App (Zulkhairil, 2021b). The "Information" section (the writing of the revised article was on July 16th, 2021) had not been updated since May 29th, 2020 regarding West Java Governor Decree No. 443/Kep.287Hukham/2020. Visually, infographics were no different from other cities/districts. The city government did not collaborate with anthropologists, communication experts, and Bandung City artists to make master designs for socialization. Such collaborations could produce interesting designs that conformed to the characteristics of Bandung City residents by making unique designs, propagating more popular and understandable narratives, creating mascots - for example, Kabayan or Cepot - as "socialization ambassadors", and so on.

We may review the innovations of the Makassar City Government implemented by the Makassar City Regional Library Office as a comparison. Since the pandemic, the institution had created the Dongkelor program (Dongeng Keliling Online dari Rumah - Online mobile storytelling from home) by expanding Mobile Library and Storytelling Services (Mobile Library). The program provides educational content for children on social media, including education on health protocols. On May 2nd, 2020, the Dongkelor program was live on the IG account @ dongkelperpusling with hundreds of viewers. Therefore, since June 2020, the program has started to penetrate the Youtube channel (June 2020).

\section{E. CONCLUSION}

Williams' (2019) approach helped this article analyze the Bandung City Government's capacity to handle the COVID-19 pandemic. In crises - situations when unexpected problems from a wide spectrum of aspects appear simultaneously in a short time-individual capacity also determines the government's capacity. Bandung City Government had implemented several policies to deal with the pandemic, but the curve for the spread of COVID-19 was not flattening. This signifies that Bandung City Government had weak or low capacity due to the centralization of policies handling the pandemic and inadequate individual capacity.

Centralization dulled the ability of the Bandung City Government to get out of the pandemic crisis, which resulted in low citizen trust and participation. In the context of Indonesia, the capacity of each regional government is not the same (human resources, budget, health facilities, culture, characteristics of residents, emerging impacts, etc.). It is urgently needed to find the synergy between the central and regional governments to reduce the transmission rate of COVID-19. The decentralization system does not have the same pattern because each region has different characteristics and needs. However, the similarity is that finding synergies is an open, data-based, systematic, and non-random learning process.

It is difficult to expect individual capacity to increase the government's capacity in handling the pandemic if it puts the "old faces" of bureaucrats in the process. That may turn the handling of the pandemic into trivial routines with dreary procedures up in its old stocks. Information management - when the virus is one step ahead of scientific findings - becomes ammunition for the apparatus to exercise discretion, in addition to giving inputs starting from the process of formulating to evaluating policies. For this reason, a collaboratively managed data bank by many fields (epidemiology, public health, medicine, sociology, communication, IT) is essential.

\section{REFERENCES}

Agustino, L. (2020). Analisis Kebijakan Penanganan Wabah Covid-19: Pengalaman Indonesia. Junal Borneo Administrator, 16(2), 253-270. https://doi.org/10.24258/jba.v16i2.685

Agustino, L., \& Wicaksana, H. H. (2020). Policy Analysis of Handling COVID-19: Experience China, South Korea, Italy, and Indonesia. Journal of Governance, 5(2). https://doi.org/10.31506/jog.v5i2.8683 
Andrews, M., Pritchett, L., \& Woolcock, M. (2017). Building State Capability: Evidence, Analysis, Action. Oxford University Press.

Ang, Y. Y. (2016). How China Escaped the Poverty Trap. Cornell University Press.

Ansell, C., \& Gash, A. (2008). Collaborative Governance in Theory and Practice. Journal of Public Administration Research and Theory, 18(4), 543-571. https://doi.org/10.1093/JOPART/MUM032

Anshori, A. Y. (2020). Website Pusicov Tidak Bisa Diakses, Warga Kota Bandung Bisa Cek Informasi Covid-19 di Sini. https://prfmnews.pikiran-rakyat.com/bandung-raya/pr13756766/website-pusicov-tidak-bisa-diakses-warga-kota-bandung-bisa-cek-informasicovid-19-di-sini

Azzis Zulkhairil. (2020). Dituding Tidak Koordinasi PSBM dengan RW, Ini Jawaban Pemkot Bandung. https://jabar.idntimes.com/news/jabar/azzis-zilkhairil/dituding-tidak-koordinasipsbm-dengan-rw-ini-jawaban-pemkot-bandung

Baker, B. (2010). Resource Constraint and Policy in Liberia's Post-conflict Policing. An International Journal, 11(3), 184-196. https://doi.org/10.1080/15614260902742168

Baser, H. (2011). Perspectives on Capacity Development in Fragile Situations.

BBCNews. (2020). Virus Corona: Jokowi Umumkan Langkah Pengendalian Covid-19, tapi Tanpa "Komando Nasional" - BBC News Indonesia. https://www.bbc.com/ indonesia/indonesia51897307

Bersch, K., Praça, S. E., \& Taylor, M. M. (2017). State Capacity, Bureaucratic Politicization, and Corruption in the Brazilian State. Governance: An International Journal of Policy, Administration, and Institutions, 30(1), 105-124. https://doi.org/10.1111/gove.12196

Besley, T., \& Persson, T. (2011). Pillars of Prosperity. Princeton University Press.

Bozeman, B. (1987). All Organizations are Public : Bridging Public and Private Organizational Theories (1st ed.). Jossey-Bass.

Bramasta, D. B. (2020). IDI Sebut Angka Kematian Terkait Corona di Indonesia Lebih dari 1.000 Kasus. $\quad$ https://www.kompas.com/tren/read/2020/04/19/112918065/idi-sebut-angkakematian-terkait-corona-di-indonesia-lebih-dari-1000-kasus?page=all

Centeno, M., Kohli, A., \& Yashar, D. (2017). Unpacking States in the Developing World: Capacity. Performance, and Politics. In M. Centeno, A. Kohli, \& D. Yasha (Eds.), States in the Developing World (pp. 1-32). Cambridge University Press.

CNNIndonesia. (2020). Bioskop di Bandung Mulai Buka, Kasus Covid Diklaim Terkendali. https://www.cnnindonesia.com/nasional/20201011165258-20-557096/bioskop-di-bandungmulai-buka-kasus-covid-diklaim-terkendali

Creswell, J. W. (2009). Research design: Qualitative, Quantitative, and Nixed Methods Approaches (3rd ed.). Sage Publications.

D’Arcy, M., \& Nistotskaya, M. (2020). State Capacity, Quality of Government, Sequencing and Development Outcomes. In M. Bågenholm, M. Bauhr, M. Grimes, \& B. Rothstein (Eds.), Oxford Handbook of the Quality of Government. Oxford University Press.

Detikcom. (2020). Satu Pintu Informasi Corona di Tangan Pemerintah. https://news.detik.com/berita/d-4944974/satu-pintu-informasi-corona-di-tanganpemerintah?single $=1$

Djalante, R., Lassa, J., Setiamarga, D., Sudjatma, A., Indrawan, M., Haryanto, B., Mahfud, C., Sinapoy, M. S., Djalante, S., Rafliana, I., Gunawan, L. A., Surtiari, G. A. K., \& Warsilah, H. (2020). Review and analysis of current responses to COVID-19 in Indonesia: Period of January to March 2020. Progress in Disaster Science, 6, 100091. https://doi.org/10.1016/j.pdisas.2020.100091

Doremalen, N. van, Bushmaker, T., Morris, D. H., Holbrook, M. G., Gamble, A., Williamson, B. N., Tamin, A., Harcourt, J. L., Thornburg, N. J., Gerber, S. I., Lloyd-Smith, J. O., Wit, E. de, \& Munster, V. J. (2020). Aerosol and Surface Stability of SARS-CoV-2 as Compared with 
SARS-CoV-1. The New England Journal of Medicine, 382, 1564-1567. https://doi.org/10.1056/NEJMc2004973

Farisa, F. C. (2020). LP3ES Catat Ada 37 Pernyataan Blunder Pemerintah soal Covid-19 Kompas.com. https://nasional.kompas.com/read/2020/04/06/17522121//p3es-catat-ada-37pernyataan-blunder-pemerintah-soal-covid-19?page=all

Garicano, L., \& Rayo, L. (2016). Why Organizations Fail: Models and Cases. Journal of Economic Literature, 54(1), 137-192. https://doi.org/10.1257/JEL.54.1.137

Gibbons, R., \& Henderson, R. (2012). What Do Managers Do? Exploring Persistent Performance Differences among Seemingly Similar Enterprises. https://www.hbs.edu/ris/Publication Files/13-020.pdf

Gofen, A., \& Lotta, G. (2021). Street-Level Bureaucrats at the Forefront of Pandemic Response: A Comparative Perspective. Https://Doi.Org/10.1080/13876988.2020.1861421, 23(1), 3-15. https://doi.org/ 10.1080/13876988.2020.1861421

Gomide, A. A., \& Pereira, A. K. (2018). The Concept of State Capacity and Its Operationalization in Empirical Research (Issue June).

Hartmann, M. R. K., \& Hartmann, R. K. (2021). Frontline Innovation in Times of Crisis: Learning from the Corona Virus Pandemic. Policing: A Journal of Policy and Practice, 14(4), 10921103. https://doi.org/10.1093/POLICE/PAAA044

Herdiana, D., Mukhlis, M., \& Madya, F. (2021). Strengthening the Capacity of Local Government in Tackling Covid-19. https://www.researchgate.net/publication/351063487_Strengthening_the_Capacity_of_Loca 1_Government_in_Tackling_Covid-19

Hikam, H. A. Al. (2020). Hadapi Wabah Corona di RI, Komunikasi Jokowi-Terawan Belepotan. https://finance.detik.com/berita-ekonomi-bisnis/d-4974136/hadapi-wabah-corona-di-rikomunikasi-jokowi-terawan-belepotan

Hill, C. J. (2005). Casework Job Design and Client Outcomes in Welfare-to-Work Offices. Journal of Public Administration Research and Theory, 16, 263-288. https://doi.org/10.1093/jopart/mui043

Hills, A. (2007). Police Commissioners, Presidents and the Governance of Security. The Journal of Modern African Studies, 45(3), 403-423. https://doi.org/ 10.1017/S0022278X07002686

Ihsanuddin, \& Hakim, R. N. (2020). Atasi Covid-19, Jokowi Minta Kepala Daerah Tak Buat Kebijakan Sendiri. https://nasional.kompas.com/read/2020/03/31/15314231/atasi-covid-19jokowi-minta-kepala-daerah-tak-buat-kebijakan-sendiri

Iqbal, M. (2021). Akibat Pandemi COVID-19, 40 Ribu Warga Bandung Jadi Miskin Baru. https://news.detik.com/berita-jawa-barat/d-5341840/akibat-pandemi-covid-19-40-ribuwarga-bandung-jadi-miskin-baru

IRGC. (2017). Introduction to the IRGC Risk Governance Framework, revised version. Lausanne: EPFL International Risk Governance Center, 1-52.

Jaffrey, S. (2020). Coronavirus Blunders in Indonesia Turn Crisis Into Catastrophe. Carnegie Endowment for International Peace. https://carnegieendowment.org/2020/04/29/ coronavirus-blunders-in-indonesia-turn-crisis-into-catastrophe-pub-81684

Janssen, M., \& Voort, H. van der. (2020). Agile and Adaptive Governance in Crisis Response: Lessons from the COVID-19 Pandemic. International Journal of Information Management, 55. https://doi.org/10.1016/j.ijinfomgt.2020.102180

Kaufmann, D., Kraay, A., \& Mastruzzi, M. (2015). The Worldwide Governance Indicators: Methodology and Analytical Issues. Hague Journal on the Rule of Law, 3(2), 220-246. https://doi.org/10.1017/S1876404511200046

kemkes.go.id. (2020). Kemenkes Sarankan 3 Jenis Masker untuk Dipakai.

Kim, M. H., Cho, W., Choi, H., \& Hur, J. Y. (2020). Assessing the South Korean Model of 
Emergency Management during the COVID-19 Pandemic. Asian Studies Review, 1-12. https://doi.org/10.1080/10357823.2020.1779658

Kocher, M. A. (2010). State Capacity as a Conceptual Variable. Yale Journal of International Affairs, 5(2), 137-145. https://www.yalejournal.org/publications/state-capacity-as-aconceptual-variable

Kominfo. (2020). Laporan Isu Hoaks Maret 2020.

Kuipers, N., Mujani, S., \& Pepinsky, T. (2020). Encouraging Indonesians to Pray From Home During the COVID-19 Pandemic. Journal of Experimental Political Science, 1-12. https://doi.org/10.1017/XPS.2020.26

kumparan. (2020). Pemprov Jabar soal Nasib Masker Scuba Senilai Rp 40 M: Insya Allah Tak Mubazir. https://kumparan.com/kumparannews/pemprov-jabar-soal-nasib-masker-scu basenilai-rp-40-m-insya-allah-tak-mubazir-1uF8SyQiFcU/full

Ladiqi, S. (2020). State Capacity and Public Trust in Handling the COVID-19 Outbreak in Malaysia. Global Strategis, 14(2), 257-274. https://doi.org/10.20473/JGS.14.2.2020.257-274

Lindvall, J., \& Teorell, J. (2016). State Capacity as Power: A Conceptual Framework.

Mann, M. (1984). The Autonomous Power of the State: Its Origins, Mechanisms and Results. European Journal of Sociology, 25(2), 185-213. https://doi.org/10.1017/S0003975600004239

Mas'udi, W., \& Winanti, P. S. (2020). Covid-19: Dari Krisis Kesehatan ke Krisis Tata Kelola. In P. S. Winanti \& W. Mas'udi (Eds.), Tata Kelola Penanganan Covid-19 di Indonesia: Kajian Awal (1st ed.). UGM Press.

Merriam, S. B. (1998). Qualitative Research and Case Study Applications in Education. JosseyBass.

Mujani, S. (2020). Asesmen Publik atas Kinerja Pemerintah Indonesia Menangani Wabah COVID-19: Sebuah Penjelasan Ekonomi Politik. Jurnal Penelitian Politik, 17(2), 159-178. file:///D:/Downloads/871-2755-2-PB.pdf

Mujani, S., \& Irvani, D. (2020). Sikap dan Perilaku Warga terhadap Kebijakan Penanganan Wabah Covid-19. Politika: Jurnal Ilmu Politik, 11(2), 219-238. https://doi.org/10.14710/POLITIKA.11.2.2020.219-238

Naurah, N., \& Ferdianti, S. (2020). Bagaimana Kondisi Politik Indonesia di Tengah Pandemi Covid-19? https://ketik.unpad.ac.id/posts/528/bagaimana-kondisi-politik-indonesia-ditengah-pandemi-covid-19-1

Perdana, P. P. (2020a). 189 Pegawai dan ASN Pemkot Bandung Positif Covid-19. https://regional.kompas.com/read/2020/09/12/06444871/189-pegawai-dan-asn-pemkotbandung-positif-covid-19

Perdana, P. P. (2020b). Dampak Covid-19, Terdata 3.396 Pekerja Kena PHK di Kota Bandung. https://bandung.kompas.com/read/2020/05/01/06534401/dampak-covid-19-terdata-3396pekerja-kena-phk-di-kota-bandung?page $=$ all

Perry, J. L., \& Rainey, H. G. (1988). The Public-Private Distinction in Organization Theory: A Critique and Research Strategy. The Academy of Management Review, 13(2), 182. https://doi.org/10.2307/258571

Pikobar. (2021). Pusat Informasi dan Koordinasi COVID-19 Jawa Barat. https://pikobar.jabarprov.go.id/data

Popovic, N. (2020). New Social Compact The State and Globalization during Covid-19. Modern Diplomacy. https://moderndiplomacy.eu/2020/04/13/the-state-an

Ramadhan, D. I. (2020). Soal Pelarangan Masker Scuba, Ini Respons Wawalkot Bandung. https://news.detik.com/berita-jawa-barat/d-5184726/soal-pelarangan-masker-scuba-inirespons-wawalkot-bandung

Rinaldo. (2021). 772 Pegawai ASN dan Non-ASN Pemkot Bandung Terpapar Covid-19 - News Liputan6.com. https://www.liputan6.com/news/read/4595621/772-pegawai-asn-dan-non- 
asn-pemkot-bandung-terpapar-covid-19

Ritonga, M. W. (2020). Jabar Hadapi Siaga Satu Persebaran Virus Korona - Kompas.id. Kompas.Id. https://www.kompas.id/baca/nusantara/2020/03/02/jabar-hadapi-siaga-satupersebaran-virus-korona

Riyadi, T. (2021). Dampak Pandemi Covid-19, Pertumbuhan Ekonomi Kota Bandung Minus 2 Persen. $\quad$ https://prfmnews.pikiran-rakyat.com/bandung-raya/pr-131542841/dampakpandemi-covid-19-pertumbuhan-ekonomi-kota-bandung-minus-2-persen

Santoso, T. (2020). Relasi Pusat-Daerah dalam Menangani COVID-19 di Indonesia. Jurnal Ilmu Administrasi Media Pengembangan Ilmu Dan Praktek Administrasi, 17(2). https://doi.org/10.31113/jia.v17i2.571

Shepsle, K. A. (1992). Congress is a "They," not an "It": Legislative Intent as Oxymoron. International Review of Law and Economics, 12(2), 239-256. https://doi.org/10.1016/01448188(92)90043-Q

Simbolon, H. (2020). Dilema Pembukaan Bioskop, Setumpuk Catatan dari Pemkot Bandung untuk Pengelola. https://www.liputan6.com/regional/read/4381355/dilema-pembukaan-bioskopsetumpuk-catatan-dari-pemkot-bandung-untuk-pengelola

Sitorus, A. A., \& Rahmadi, M. F. (2021). Disinkronisasi Kebijakan Pemerintah Indonesia dalam Penanganan COVID-19. Jurnal Renaissance, 6(1), 721-732. http://www.ejournalacademia.org/index.php/renaissance

Skocpol, T. (1985). Bringing the State Back in: Strategies of Analysis in Current Research. In P. Evans, D. Rueschemeyer, \& T. Skocpol (Eds.), Bringing the State Back In (pp. 3-43). Cambridge University Press.

Soifer, H. (2008). State Infrastructural Power: Approaches to Conceptualization and Measurement. Studies in Comparative International Development, 43, 231-251. https://doi.org/10.1007/s12116-008-9028-6

Soifer, H., \& Hau, M. vom. (2008). Unpacking the strength of the State: The utility of State infrastructural power. Studies in Comparative International Development, 43(3-4), 219-230. https://doi.org/10.1007/s12116-008-9030-z

Weber, M. (2007). From Max Weber: Essays in Sociology (H. H. Gerth \& C. W. Mills (eds.)). Routledge.

WHO. (2020). Viet Nam Adopts WHO Outbreak Investigation Tool for COVID-19, Other Infectious Diseases. https://www.who.int/vietnam/news/detail/23-03-2020-viet-nam-adoptswho-outbreak-investigation-tool-for-covid-19-other-infectious-diseases

Wijanarko, Y. (2020). Forum RW di Bandung Belum Paham PSBM, Tetap Utamakan Protokol Kesehatan 3M - Pikiran-Rakyat.com. https://www.pikiran-rakyat.com/bandung-raya/pr01838733/forum-rw-di-bandung-belum-paham-psbm-tetap-utamakan-protokol-kesehatan$3 \mathrm{~m}$

Williams, M. J. (2019). Beyond State Capacity: Bureaucratic Performance, Policy Implementation, and Reform. https://martinjwilliamsdotcom.files.wordpress.com/2019/12/williams-dec2019-beyondstate-capacity.pdf

Wilson, J. (1989). Bureaucracy. Basic Books.

Worldometers. (2021). Coronovirus Cases. https://www.worldometers.info/coronavirus/country/ Yuantisya, M. (2021). Menilik Kebijakan Pemerintah pada Sektor Pendidikan dalam Setahun Pandemi Covid-19. https://www.pikiran-rakyat.com/nasional/pr-011521792/menilikkebijakan-pemerintah-pada-sektor-pendidikan-dalam-setahun-pandemi-covid-19

Zandamela, H., \& Mphahlele, M. (2021). Local Government Capacity Development: A Case Study of a South African District Municipality. Journal of Public Administration and Governance, 11(2), 156. https://doi.org/10.5296/jpag.v11i2.18373 
Zulkhairil, A. (2021a). Data COVID-19 Amburadul, Angka Kelurahan dan Pusicov Beda. https://jabar.idntimes.com/news/jabar/azzis-zilkhairil/data-covid-19-bandung-amburadulangka-kelurahan-dan-pusicov-beda

Zulkhairil, A. (2021b). Data COVID-19 Berbeda, Ini Pembelaan Dinkes Kota Bandung. https://jabar.idntimes.com/news/jabar/azzis-zilkhairil/data-pikobar-jabar-dan-pusicovbandung-berbeda-ini-pembelaan-dinkes 